\title{
Does genetic anticipation occur in familial Alexander disease?
}

\author{
Camille K. Hunt ${ }^{1} \cdot$ Ahmad AI Khleifat $^{1} \cdot$ Ella Burchill $^{1} \cdot$ Joerg Ederle $^{2} \cdot$ Ammar Al-Chalabi $^{1} \cdot$ Jemeen Sreedharan $^{1}$ (I)
}

Received: 8 January 2021 / Accepted: 18 April 2021 / Published online: 28 May 2021

(c) The Author(s) 2021

\begin{abstract}
Alexander Disease (AxD) is a rare leukodystrophy caused by missense mutations of glial fibrillary acidic protein (GFAP). Primarily seen in infants and juveniles, it can present in adulthood. We report a family with inherited AxD in which the mother presented with symptoms many years after her daughter. We reviewed the age of onset in all published cases of familial AxD and found that 32 of 34 instances of parent-offspring pairs demonstrated an earlier age of onset in offspring compared to the parent. We suggest that genetic anticipation occurs in familial AxD and speculate that genetic mosaicism could explain this phenomenon.
\end{abstract}

Keywords Alexander disease $\cdot$ GFAP $\cdot$ Anticipation $\cdot$ Mosaicism

\section{Case history}

The proband had no prior medical history and normal early development. She presented to the neurology department aged 45 with an 8-month history of stiffness in all four limbs and poor balance. Despite this, she was running a café independently. There were no sphincter or sensory disturbances. Examination revealed poorly responsive pupils, a prominent jaw jerk and slight dysarthria. She had slow, spastic speech and slow tongue movements with no tongue wasting. She had marked spasticity in all limbs with brisk reflexes, which was slightly worse on the left, with normal strength except for the left first dorsal interosseous muscle (MRC grade 4). Her plantar reflexes were equivocal. There were no lower motor neuron features, no cerebellar signs and sensory examination was normal.

MRI scans of her brain and cervical spine were conducted at her local hospital and reported as normal. Spinal fluid demonstrated normal cellular constituents, normal glucose and CSF protein and no oligoclonal bands. Clinical

Camille K. Hunt and Ahmad Al Khleifat contributed equally to this work.

Jemeen Sreedharan

Jemeen.sreedharan@kcl.ac.uk

1 Department of Basic and Clinical Neuroscience, King's College London, London, UK

2 Department of Neuroradiology, King's College Hospital NHS Trust, London, UK neurophysiology assessments demonstrated normal nerve conduction and electromyography. However, central motor conduction times to intrinsic hand and foot muscles were markedly increased. Collectively, these findings were consistent with a progressive, degenerative purely upper motor neuron syndrome affecting limbs and with a pseudobulbar component. A presumptive diagnosis of primary lateral sclerosis was made and baclofen was commenced to treat spasticity. Her condition progressively deteriorated, impairing her mobility such that she had to retire from work. Six years after symptom onset, aged 51, she remained free of lower motor neuron signs. She was then lost to follow-up.

Three years after the proband's last assessment, her 71-year-old mother presented to our clinic with a history strikingly reminiscent of her daughter's ailments. The patient described weakness progressing over 4 years with recent dysphagia. At presentation she was wheelchair dependent. Examination demonstrated extreme weight loss, prominent palmomental reflexes, a bovine cough and spastic, dysarthric speech. No muscle wasting or fasciculations were observed in cranial or limb territories. Tone was increased in all limbs, with a pyramidal pattern of weakness, MRC grade 4 in the proximal limb muscles. Deep tendon reflexes were brisk and plantars were extensor. Brain MRI demonstrated cervicomedullary atrophy (Fig. 1a, b) suggesting a diagnosis of adult-onset AxD. A DNA sample for GFAP mutation screening to confirm the diagnosis could not be obtained, as the patient developed a chest infection and died soon after her 

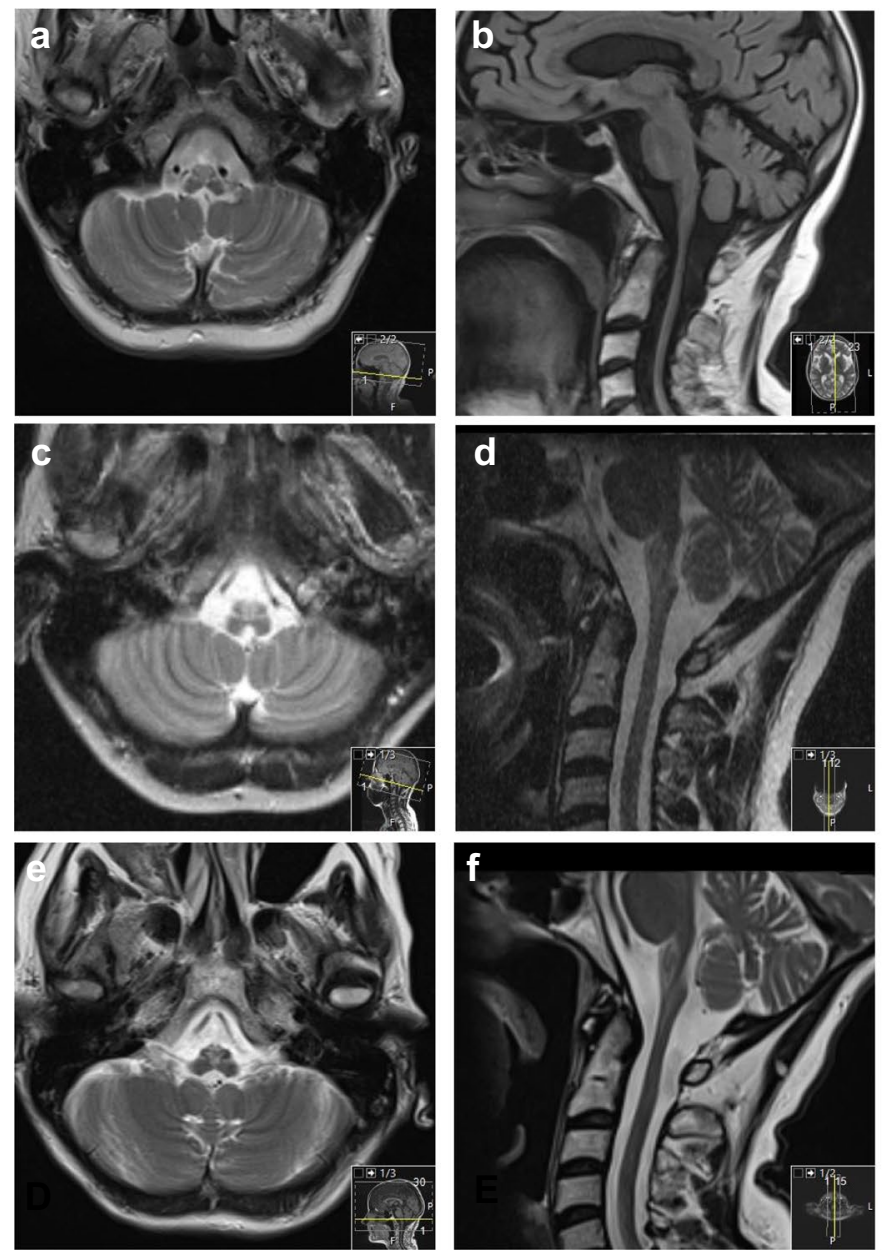

g
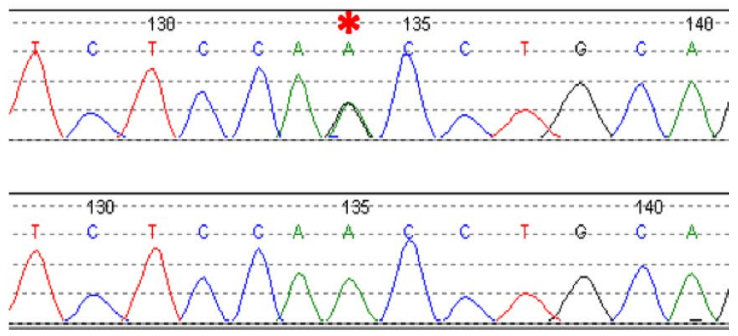

$\mathbf{h}$

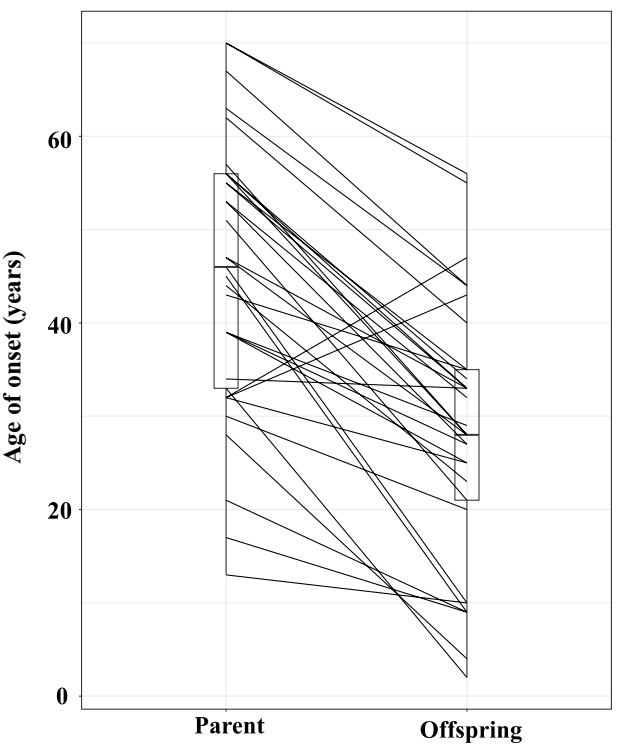

Fig. 1 a-f MRI scans of proband and mother. Axial T2 (a) and parasagittal FLAIR (b) of proband's mother at the time of presentation showing upper cervical spinal cord and medullary volume loss and demyelination. Axial T2 (c) and sagittal T2 (d) of proband at initial presentation and at the time of re-call to clinic (e, f). $\mathbf{g}$ DNA chromatograms demonstrating proband's DNA sequence (top, GFAP mutation highlighted with asterisk) and a control DNA sequence. $\mathbf{h}$ Paired

MRI scan. However, we reconnected with the proband who returned to clinic for review.

By now, aged 54, the proband was wheelchair dependent. She reported intermittent choking on food. On neurological examination, she was alert and oriented. The pupils were equal at $3 \mathrm{~mm}$ and slowly reactive to light. She had weakness of neck flexion, a weak cough, spastic speech and a brisk jaw jerk. In addition to marked spasticity in all four limbs, she had proximal weakness of grade 4 in both upper and lower limbs in a pyramidal pattern, and all deep tendon reflexes were brisk. There were no lower motor neuron signs and no sensory deficits.

She underwent a repeat MRI brain scan (Fig. 1e, f), which showed marked thinning of the medulla oblongata and cervical cord at the cervicomedullary junction. Increased T2 cord signal/FLAIR foci were noted in the boxplot comparing age of onset between 34 parents and 34 offspring with familial AxD. Lines between boxplots represent individual parent-offspring pairs. Boxplot bars indicate 95\% confidence intervals. PairedData package was used to generate the effect plot on R. Paired sample $t$ test showed a mean $14 \%$ decrease in age of onset in the offspring group compared to parents $\left(p=2.02 \times 10^{-9}, 95 \% \mathrm{CI}\right.$ for the difference 12.64-20.93 years)

medulla with global cerebral atrophy in excess for her age. These features were similar to those of her mother and consistent with adult-onset AxD. Her previous imaging was obtained for comparison and on review by a specialist neuroradiologist was concluded to be consistent with AxD (Fig. 1c, d). A DNA sample was obtained and sequencing showed heterozygosity for the GFAP mutation c.1157A $>$ G (p.Asn386Ser) (Fig. 1g). This mutation occurs in the C-terminal tail domain of GFAP and is predicted to be deleterious, with a combined annotationdependent depletion score of 23.3 (CADD v1.6). The same sequence change has been reported several times in patients with $\mathrm{AxD}[1,2]$ but only once in the gnomAD database of controls. Ours is the first description of this mutation in a case of familial AxD. 


\section{Analysis of familial Alexander disease}

An intriguing aspect of this family is that the age of symptom onset in the mother was greater than in the daughter by over two decades. Variable expressivity occurs in AxD $[3,4]$, but here both mother and daughter had strikingly similar phenotypes. Whilst variable penetrance of the GFAP mutation could explain the daughter's much earlier age of onset, another possibility is genetic anticipation. To investigate further, we reviewed all previously published cases of familial AxD, searching Pubmed using the criteria "alexander [title] disease [title]". We identified 22 studies reporting 37 instances of inherited AxD (Table 1) [3, 3-25]. Data on age of onset was available for 34 parents (27 female: 7 male) and 34 offspring (17 female: 17 male). The mean age of onset in the affected parents was 43.8 years (95\% CI 38.2-49.4 years), and in offspring, 27.4 years (95\% CI 22.4-32.4 years) (Fig. 1h). Paired sample $t$ test showed a mean $14 \%$ decrease of the age of onset in the offspring group compared to parents $\left(p=2.02 \times 10^{-9}\right.$, 95\% CI for the difference $12.64-20.93$ years). This suggests that genetic anticipation is influencing disease onset in AxD.
Table 1 Summary of published cases of familial Alexander disease. Cases highlighted in blue text showed earlier age of onset in parent compared to offspring, whilst other cases demonstrated earlier age of onset in offspring. Purple cases were excluded from analysis as age of onset (actual or approximate) for either parent or offspring was not given or parent was asymptomatic. $A o O$, age of onset. N/A not applicable as asymptomatic

\begin{tabular}{|c|c|c|c|c|c|c|c|}
\hline $\begin{array}{l}\text { AoO } \\
\text { Parent }\end{array}$ & Sex & Mutation & $\begin{array}{l}\text { AoO } \\
\text { Offsprin } \\
\text { g }\end{array}$ & $\begin{array}{l}\text { Se } \\
\mathbf{x}\end{array}$ & Mutation & Notes & $\begin{array}{l}\text { Supplementary } \\
\text { Reference }\end{array}$ \\
\hline 67 & $\mathrm{~F}$ & Not done & 44 & $\mathrm{~F}$ & N386S & & Current study \\
\hline \multirow[b]{2}{*}{56} & \multirow[b]{2}{*}{$\mathrm{F}$} & M45II & 33 & $\mathrm{~F}$ & M45II & & {$[5]$} \\
\hline & & M45II & 34 & $\mathrm{M}$ & M45II & & {$[5]$} \\
\hline 46 & $\mathrm{~F}$ & G18V & 10 & $\mathrm{M}$ & G18V & & {$[6]$} \\
\hline 17 & $\mathrm{~F}$ & G18V & 9 & $\mathrm{M}$ & G18V & & [6] \\
\hline 47 & $\mathrm{~F}$ & not done & 28 & $\mathrm{~F}$ & R416W & $\begin{array}{l}\text { 47F had maternal aunt with similar but mild symptoms with } \mathrm{AoO} \text { of } 54 \text { (progressing } \\
\text { slowly) }\end{array}$ & [7] \\
\hline \multirow[b]{2}{*}{70} & \multirow[b]{2}{*}{$\mathrm{F}$} & not done & 56 & $\mathrm{~F}$ & $\mathrm{D} 78 \mathrm{~N}$ & & {$[8]$} \\
\hline & & not done & 55 & $\mathrm{~F}$ & D78N & & {$[8]$} \\
\hline 57 & $\mathrm{M}$ & $\begin{array}{l}\text { A330G \& } \\
\text { G332L }\end{array}$ & 28 & $\mathrm{M}$ & $\begin{array}{l}\text { A330G \& } \\
\text { G332L }\end{array}$ & $57 \mathrm{M}$ has affected sibling, AoO $53 \mathrm{~F}$ & [9] \\
\hline 47 & $\mathrm{~F}$ & not done & 33 & $\mathrm{~F}$ & E373A & & {$[10]$} \\
\hline 44 & $\mathrm{M}$ & not done & 23 & $\mathrm{M}$ & S385C & & [10] \\
\hline 63 & $\mathrm{~F}$ & not done & 44 & $\mathrm{M}$ & not done & neither case genetically confirmed & [10] \\
\hline 30 & $\mathrm{~F}$ & $\mathrm{Y} 242 \mathrm{~N}$ & 20 & $\mathrm{M}$ & $\mathrm{Y} 242 \mathrm{~N}$ & $\begin{array}{l}\text { The son was only able to pull himself up to stand after 1y of age. He performed } \\
\text { exercise poorly around the time he entered high school. Age } 20 \text {, diagnosed with } \\
\text { developmental disorder. Age } 35 \text {, lightheaded and prone to falling. }\end{array}$ & [11] \\
\hline 34 & $\mathrm{~F}$ & not done & 33 & $\mathrm{~F}$ & S393I & $33 \mathrm{~F}$ is mother of patient below & [12] \\
\hline 33 & $\mathrm{~F}$ & S393I & 2 & $\mathrm{M}$ & S393I & $33 \mathrm{~F}$ is daughter of patient above & [12] \\
\hline 56 & $\mathrm{M}$ & $\begin{array}{l}\text { R330G \& } \\
\text { E332K }\end{array}$ & 28 & $\mathrm{M}$ & $\begin{array}{l}\text { R330G \& } \\
\text { E332K }\end{array}$ & 56M has two sisters AoO 53y; asymptomatic & [13] \\
\hline \multirow[b]{3}{*}{39} & \multirow[b]{3}{*}{$\mathrm{F}$} & \multirow[b]{3}{*}{ Not done } & 25 & $\mathrm{~F}$ & not done & $\begin{array}{l}\text { Additional arm of this family appear to have AxD as well, but no details on AoO. } \\
\text { MRI and pathology but no genetics. } 39 \mathrm{~F} \text { said to have had AoO in 'late } 30 \mathrm{~s} \text { ' }\end{array}$ & [14] \\
\hline & & & 27 & $\mathrm{M}$ & not done & & [14] \\
\hline & & & 29 & $\mathrm{~F}$ & not done & & [14] \\
\hline 62 & $\mathrm{~F}$ & E223Q & 40 & $\mathrm{M}$ & E223Q & not stated that mother is suspected of being afflicted by AOAD & [15] \\
\hline 53 & $\mathrm{~F}$ & V87G & 27 & F & V87G & & [16] \\
\hline 53 & $\mathrm{~F}$ & V87G & 32 & $\mathrm{M}$ & V87G & In offspring, hyperreflexia and extensor plantar noted age 32 & {$[16]$} \\
\hline 32 & $\mathrm{M}$ & D417A & 43 & $\mathrm{~F}$ & $\mathrm{D} 417 \mathrm{~A}$ & Offspring has later $\mathrm{AoO}$ than parent & {$[17-19]$} \\
\hline 32 & $\mathrm{M}$ & D417A & 25 & $\mathrm{~F}$ & not done & & {$[17-19]$} \\
\hline 32 & M & D417A & 47 & $\mathrm{~F}$ & not done & Offspring has later $\mathrm{AoO}$ than parent & {$[17-19]$} \\
\hline 43 & $\mathrm{~F}$ & $\begin{array}{l}\text { D417A- } \\
\text { inferred }\end{array}$ & 35 & $\mathrm{~F}$ & not done & Offpsring AoO noted as 'in $30 \mathrm{~s}^{\prime}$ & [17-19] \\
\hline 45 & $\mathrm{~F}$ & Q426L & 9 & $\mathrm{~F}$ & Q426L & $\begin{array}{l}\text { Offspring had scoliosis age } 9 \text {. Bipolar disease. Died aged } 21 \text { from alcohol overdose. } \\
\text { Had GFAP pathology }\end{array}$ & [17] \\
\hline 55 & $\mathrm{~F}$ & D78E & 35 & $\mathrm{~F}$ & D78E & & {$[3]$} \\
\hline 55 & F & D78E & 33 & $\mathrm{M}$ & D78E & & [3] \\
\hline 51 & $\mathrm{M}$ & D78E & 21 & $\mathrm{~F}$ & D78E & Parental $\mathrm{AoO}$ noted as ' $>50^{\prime}$ '. Offspring $\mathrm{AoO}{ }^{\prime}>20^{\prime}$ & [3] \\
\hline 21 & $\mathrm{~F}$ & D78E & 9 & $\mathrm{M}$ & $\mathrm{D} 78 \mathrm{E}$ & $\begin{array}{l}\text { Parental AoO noted as '>20'. Offspring } \mathrm{AoO} \text { '<10'. Possibly from consanguineous } \\
\text { relationship }\end{array}$ & [3] \\
\hline 28 & $\mathrm{~F}$ & R376W & 4 & $\mathrm{M}$ & R376W & & {$[20]$} \\
\hline 37 & $\mathrm{~F}$ & $\mathrm{R} 416 \mathrm{~W}$ & ? & $\mathrm{M}$ & R416W & $\begin{array}{l}\text { 37F parent had scoliosis age } 12 \text {, gait disturbance age } 37 \text {. No AoO for son. Had } \\
\text { intellectual disability, AoO not given. }\end{array}$ & [21] \\
\hline 13 & $\mathrm{~F}$ & $\mathrm{R} 88 \mathrm{C}$ & 10 & $\mathrm{M}$ & $\mathrm{R} 88 \mathrm{C}$ & The mother is patient ' 3 ' and the son patient ' 4 ' in this study & [22] \\
\hline 5 & $\mathrm{~F}$ & $\begin{array}{l}\text { R88C } \\
\& D 295 \mathrm{~N}\end{array}$ & 3 & $\mathrm{M}$ & $\begin{array}{l}\text { R88C } \\
\& D 295 \mathrm{~N}\end{array}$ & $\begin{array}{l}\text { Lists AoO in childhood for both parent }\left(\mathrm{AoO}^{\prime}>4^{\prime}\right) \text { and offspring }\left(\mathrm{AoO} \mathrm{O}^{\prime}>4^{\prime}\right) \text { but says } \\
\text { that mother has classical clinical picture of adult onset } \mathrm{AxD}\end{array}$ & [23] \\
\hline N/A & F & R79H & 6 & F & $\mathrm{R} 79 \mathrm{H}$ & Daughter is patient ' 17 ' in this study. Mother was asymptomatic with MRI changes. & [24] \\
\hline 58 & $\mathrm{M}$ & Y257C & ? & $\mathrm{M}$ & not done & Offspring clearly had earlier onset but $\mathrm{AoO}$ not given. & {$[25]$} \\
\hline
\end{tabular}




\section{Discussion}

Genetic anticipation is a feature of neurological conditions linked to unstable nucleotide repeat motifs, such as Huntington's disease. Genetic anticipation has also been described in polygenic disorders including Crohn's disease and breast cancer, and in monogenic disorders such as von HippelLindau syndrome. The mechanisms underlying apparent genetic anticipation in these conditions are unclear. Statistical artefacts such as ascertainment bias may be contributing factors, but these can be controlled for [26]. Indeed, in our family, this bias is highly unlikely given that the daughter was diagnosed before her mother had any symptoms. How genetic anticipation could occur in $\mathrm{AxD}$, a disease caused largely by missense mutations, is unclear but there are several possibilities. For example, there may be a microsatellite repeat near the GFAP gene that influences its expression and expands during transmission, or epigenetic factors such as DNA methylation changes that influence GFAP expression. Alternatively, there may be linkage disequilibrium of the GFAP mutation with another variant that directly contributes to disease and gives rise to anticipation, such as a repeat expansion.

We postulate that another mechanism may explain apparent anticipation: genetic mosaicism. In $\mathrm{AxD}$, most cases are caused by de novo mutations [27]. It is plausible that if an embryo developed a spontaneous GFAP mutation beyond the single-cell stage, it would be mosaic for this mutation, which could mean that only a fraction of the nervous system would express mutant GFAP. This could attenuate disease severity and delay the age of onset. If the mutation was present in the germ cells of this mosaic patient, it could be transmitted to their offspring, who would then express the mutation ubiquitously, resulting in a more severe phenotype and earlier age of onset. Interestingly, a person with $\mathrm{AxD}$ has been described in which a GFAP mutation was found to be present in cells taken from a cheek swab, but absent from DNA extracted from blood, indicating somatic mosaicism [28]. To our knowledge, mosaicism has not previously been suggested as a cause of apparent anticipation. We were unable to test this hypothesis in our family but suggest that this should be considered in future instances of inherited AxD. This would require sequencing of DNA extracted from different brain regions at post-mortem, or, where brain tissue is unavailable, comparison of peripheral tissues, such as skin, saliva and lymphocyte derived DNA.

Acknowledgements We are grateful for the participation and assistance of the proband and her family. We are grateful to the Rare \& Inherited Disease Laboratory, London North Genomic Laboratory Hub, Great Ormond Street Hospital for performing GFAP mutation screening. This is an EU Joint Programme-Neurodegenerative Disease Research (JPND) project. The project is supported through the following funding organisations under the aegis of JPND—www.jpnd.eu (United
Kingdom, Medical Research Council (MR/L501529/1; MR/R024804/1) and Economic and Social Research Council (ES/L008238/1)). JS acknowledges funding support from the Rosetrees Trust (M799) and the van Geest Foundation. AAC is an NIHR Senior Investigator. This study represents independent research part funded by the National Institute for Health Research (NIHR) Biomedical Research Centre at South London and Maudsley NHS Foundation Trust and King's College London. AAK is funded by The Motor Neurone Disease Association and NIHR Maudsley Biomedical Research Centre.

Author contribution JS reviewed patient clinical details. CKH performed the literature search, acquired the age of onset data and generated Table 1. AA-K analysed the age of onset data. JE reviewed neuroimaging. AA-C analysed the age of onset data. EB referenced the article. JS examined the patient, designed the project and wrote the manuscript with contributions from all authors.

Funding This is an EU Joint Programme-Neurodegenerative Disease Research (JPND) project. The project is supported through the following funding organisations under the aegis of JPND—www.jpnd.eu (United Kingdom, Medical Research Council (MR/L501529/1; MR/R024804/1) and Economic and Social Research Council (ES/L008238/1)). JS acknowledges funding support from the Rosetrees Trust (M799) and the van Geest Foundation.

\section{Declarations}

Ethics approval/consent to participate Not applicable.

Consent for publication Consent was obtained from the proband of the family described.

Competing interests Ammar Al-Chalabi is a consultant for MitsubishiTanabe Pharma, GSK, and Chronos Therapeutics and chief investigator for clinical trials for Cytokinetics and OrionPharma. All other authors declare no competing interests.

Open Access This article is licensed under a Creative Commons Attribution 4.0 International License, which permits use, sharing, adaptation, distribution and reproduction in any medium or format, as long as you give appropriate credit to the original author(s) and the source, provide a link to the Creative Commons licence, and indicate if changes were made. The images or other third party material in this article are included in the article's Creative Commons licence, unless indicated otherwise in a credit line to the material. If material is not included in the article's Creative Commons licence and your intended use is not permitted by statutory regulation or exceeds the permitted use, you will need to obtain permission directly from the copyright holder. To view a copy of this licence, visit http://creativecommons.org/licenses/by/4.0/.

\section{References}

1. Lichtenstein ML, Dwosh E, Chowdhury AR et al (2017) Neurobehavioral characterization of adult-onset Alexander disease A family study. Neurol Clin Pract. https://doi.org/10.1212/CPJ. 0000000000000356

2. Draghi L, Salsano E, Farina L et al (2019) Neuropsychological features of adult form of Alexander disease. J Neurol Sci. https:// doi.org/10.1016/j.jns.2019.04.030

3. Stumpf E, Masson H, Duquette A et al (2003) Adult Alexander disease with autosomal dominant transmission: a distinct entity 
caused by mutation in the glial fibrillary acid protein gene. JAMA Neurol 60:1307-1312. https://doi.org/10.1001/archneur.60.9.1307

4. Sreedharan J, Shaw CE, Jarosz J, Samuel M (2007) Alexander disease with hypothermia, microcoria, and psychiatric and endocrine disturbances. Neurology. https://doi.org/10.1212/01.wnl. $0000259543.95222 .9 \mathrm{~d}$

5. Elmali AD, Çetinçelik Ü, Işlak C et al (2016) Familial adult-onset alexander disease: clinical and neuroradiological findings of three cases. Noropsikiyatri Ars. https://doi.org/10.5152/npa.2015.10193

6. Casasnovas C, Verdura E, Vélez V et al (2019) A novel mutation in the GFAP gene expands the phenotype of Alexander disease. J Med Genet. https://doi.org/10.1136/jmedgenet-2018-105959

7. Liu Y, Zhou H, Wang $\mathrm{H}$ et al (2016) Atypical MRI features in familial adult onset Alexander disease: Case report. BMC Neurol. https://doi.org/10.1186/s12883-016-0734-9

8. Wada Y, Yanagihara C, Nishimura Y, Namekawa M (2013) Familial adult-onset Alexander disease with a novel mutation (D78N) in the glial fibrillary acidic protein gene with unusual bilateral basal ganglia involvement. J Neurol Sci. https://doi.org/10.1016/j.jns. 2013.05.019

9. Balbi P, Seri M, Ceccherini I et al (2008) Adult-onset Alexander disease: report on a family. J Neurol. https://doi.org/10.1007/ s00415-007-0654-0

10. Graff-Radford J, Schwartz K, Gavrilova RH et al (2014) Neuroimaging and clinical features in type II (late-onset) Alexander disease. Neurology. https://doi.org/10.1212/01.wnl.0000438230. 33223.bc

11. Ogura H, Maki F, Sasaki N et al (2016) Familial adult-onset Alexander disease with a novel GFAP Mutation. Mov Disord Clin Pract. https://doi.org/10.1002/mdc3.12296

12. Salmaggi A, Botturi A, Lamperti E, et al (2007) A novel mutation in the GFAP gene in a familial adult onset Alexander disease. JNeurol. https://doi.org/10.1007/s00415-006-0361-2

13. Bachetti T, Caroli F, Bocca P et al (2008) Mild functional effects of a novel GFAP mutant allele identified in a familial case of adult-onset Alexander disease. Eur J Hum Genet. https://doi.org/ 10.1038/sj.ejhg. 5201995

14. Howard RS, Greenwood R, Gawler J et al (1993) A familial disorder associated with palatal myoclonus, other brainstem signs, tetraparesis, ataxia and Rosenthal fibre formation. J Neurol Neurosurg Psychiatry. https://doi.org/10.1136/jnnp.56.9.977

15. Brockmann K, Meins M, Taubert A et al (2003) A novel GFAP mutation and disseminated white matter lesions: adult alexander disease? Eur Neurol. https://doi.org/10.1159/000072507

16. Okamoto Y, Mitsuyama H, Jonosono M et al (2002) Autosomal dominant palatal myoclonus and spinal cord atrophy. J Neurol Sci. https://doi.org/10.1016/S0022-510X(01)00687-6
17. Messing A, Li R, Naidu S et al (2012) Archetypal and new families with Alexander disease and novel mutations in GFAP. Arch Neurol. https://doi.org/10.1001/archneurol.2011.1181

18. Seil FJ, Schochet SS, Earle KM (1968) Alexander's disease in an adult: report of a case. Arch Neurol. https://doi.org/10.1001/archn eur.1968.00480050064006

19. Schwankhaus JD, Parisi JE, Gulledge WR et al (1995) Hereditary adult-onset alexander's disease with palatal myoclonus, spastic paraparesis, and cerebellar ataxia. Neurology. https://doi.org/10. 1212/WNL.45.12.2266

20. Hirayama T, Fukae J, Noda K et al (2008) Adult-onset Alexander disease with palatal myoclonus and intraventricular tumour [6]. Eur. J, Neurol

21. Thyagarajan D, Chataway T, Li R et al (2004) Dominantly-inherited adult-onset leukodystrophy with palatal tremor caused by a mutation in the glial fibrillary acidic protein gene. Mov Disord. https://doi.org/10.1002/mds.20161

22. Van Der Knaap MS, Ramesh V, Schiffmann R et al (2006) Alexander disease: ventricular garlands and abnormalities of the medulla and spinal cord. Neurology. https://doi.org/10.1212/01.wnl.00001 98770.80743 .37

23. Tonduti D, Ardissone A, Ceccherini I et al (2016) Unusual presentations and intrafamilial phenotypic variability in infantile onset Alexander disease. Neurol Sci. https://doi.org/10.1007/ s10072-015-2466-9

24. Zang L, Wang J, Jiang Y et al (2013) Follow-up study of 22 Chinese children with Alexander disease and analysis of parental origin of de novo GFAP mutations. J Hum Genet. https://doi.org/ 10.1038/jhg.2012.152

25. Howard KL, Hall DA, Moon M et al (2008) Adult-onset Alexander disease with progressive ataxia and palatal tremor. Mov Disord. https://doi.org/10.1002/mds.21774

26. Fraser FC (1997) Trinucleotide repeats not the only cause of anticipation. Lancet. https://doi.org/10.1016/S0140-6736(05)63077-2

27. Li R, Johnson AB, Salomons $G$ et al (2005) Glial fibrillary acidic protein mutations in infantile, juvenile, and adult forms of Alexander disease. Ann Neurol. https://doi.org/10.1002/ana.20406

28. Flint D, Li R, Webster LS et al (2012) Splice site, frameshift, and chimeric GFAP mutations in Alexander disease. Hum Mutat. https://doi.org/10.1002/humu.22094

Publisher's Note Springer Nature remains neutral with regard to jurisdictional claims in published maps and institutional affiliations. 